\title{
Nevo de Spitz Angiomatoide
}

\author{
J. Lopes', D. Afonso-João², D. Teixeira', A. Baptista' \\ 'Dermatology Department, Centro Hospitalar de Vila Nova de Gaia/ Espinho, Portugal \\ 2Pathology Department, Centro Hospitalar de Vila Nova de Gaia/ Espinho, Portugal
}

RESUMO - O nevo de Spitz angiomatoide é um tumor raro que associa os aspetos clássicos do nevo de Spitz a uma componente vascular marcada. Clinicamente, manifesta-se como uma lesão papular rosada ou acastanhada, habitualmente solitária, mais frequente nas extremidades de adultos jovens. À histologia, caracteriza-se por uma proliferação de melanócitos epitelioides ou fusiformes num estroma fibroso denso, onde é evidente uma assinalável proliferação de pequenos vasos. O diagnóstico diferencial com melanoma maligno pode ser difícil, particularmente com a variante desmoplásica ou com aqueles com aspetos de regressão. O seu comportamento é benigno, comprovado pela ausência de recidivas locais ou metástases à distância durante o seguimento a longo prazo.

PALAVRAS-CHAVE - Neoplasias da Pele; Nevo de Células Epitelioides e Fusiformes.

\section{Angiomatoid Spitz Nevus}

ABSTRACT - Angiomatoid Spitz nevus is a rare tumor that combines the classic aspects of Spitz nevus with a prominent vascular component. Clinically, it presents as a pink or brownish papule, usually solitary, in the extremities of young adults. On histology, it is characterized by a proliferation of epithelioid or spindle cell melanocytes embedded in a fibrous stroma, where a dense proliferation of small vessels is evident. The differential diagnosis with malignant melanoma can be difficult, particularly with the desmoplastic variant or with those with marked regression. Its behavior is benign, as suggested by the absence of local recurrences or distant metastases during long-term follow-up.

KEYWORDS - Nevus, Epithelioid and Spindle Cell; Skin Neoplasms.

\section{INTRODUCTION}

Spitz nevus is a benign melanocytic proliferation characterized histologically by the presence of large melanocytic cells with spindle and epithelioid morphology. ${ }^{1}$ Several variants have been described to date, such as the pigmented, desmoplastic or atypical Spitz nevus. ${ }^{2}$ Because some of its aspects may resemble those of a melanoma, the differential diagnosis between the two is often difficult.

\section{CASE REPORT}

A 27-year-old woman presented to the Dermatology Department with an asymptomatic pigmented lesion on the thigh that had been present since infancy. On examination she had a 5-mm homogenous brown dome-shaped papule with an ill-defined border. On dermoscopy, a homogenous brown-grayish pattern with a central brighter area and small linear vessels were seen. No pigment network was evident. The clinical impression was that of a dermatofibroma but, due to its nonspecific character, the lesion was excised.

On histology, findings were striking. The lesion, predominantly located in the dermis, was composed of spindle and epithelioid melanocytes and a prominent vascular network dissecting through collagen fibers (Fig. 1A). The large melanocytes contained voluminous pale eosinophilic cytoplasm, enlarged oval nuclei and a prominent nucleolus. They were distributed diffusely throughout the lesion as solitary units among thick collagen bundles. No mitoses were observed. A striking feature was the presence of numerous small blood vessels with round lumina lined by a thin wall of endothelial cells without cellular atypia (Fig. 1B). Epidermis showed no significant changes, other than some degree of hyperplasia. No Kamino bodies were present. The lesion was devoid of
Correspondência: Jorge Lopes

Serviço de Dermatologia

Centro Hospitalar de Vila Nova de Gaia/ Espinho

Rua Conceição Fernandes

4434-502 Vila Nova de Gaia, Portugal

E-mail: jorge.lopes@chvng.min-saude.pt

DOI: https://dx.doi.org/10.29021/spdv.78.4.1245
Recebido/Received 2019/06/30

(C) Autor (es) (ou seu (s) empregador (es)) 2020 Revista SPDV. Reutilização permitida de acordo com CC BY-NC. Nenhuma reutilização comercial.

(c) Author(s) (or their employer(s)) 2020 SPDV Journal. Re-use permitted under CC BY-NC. No commercial re-use. 


\section{Caso Clínico}
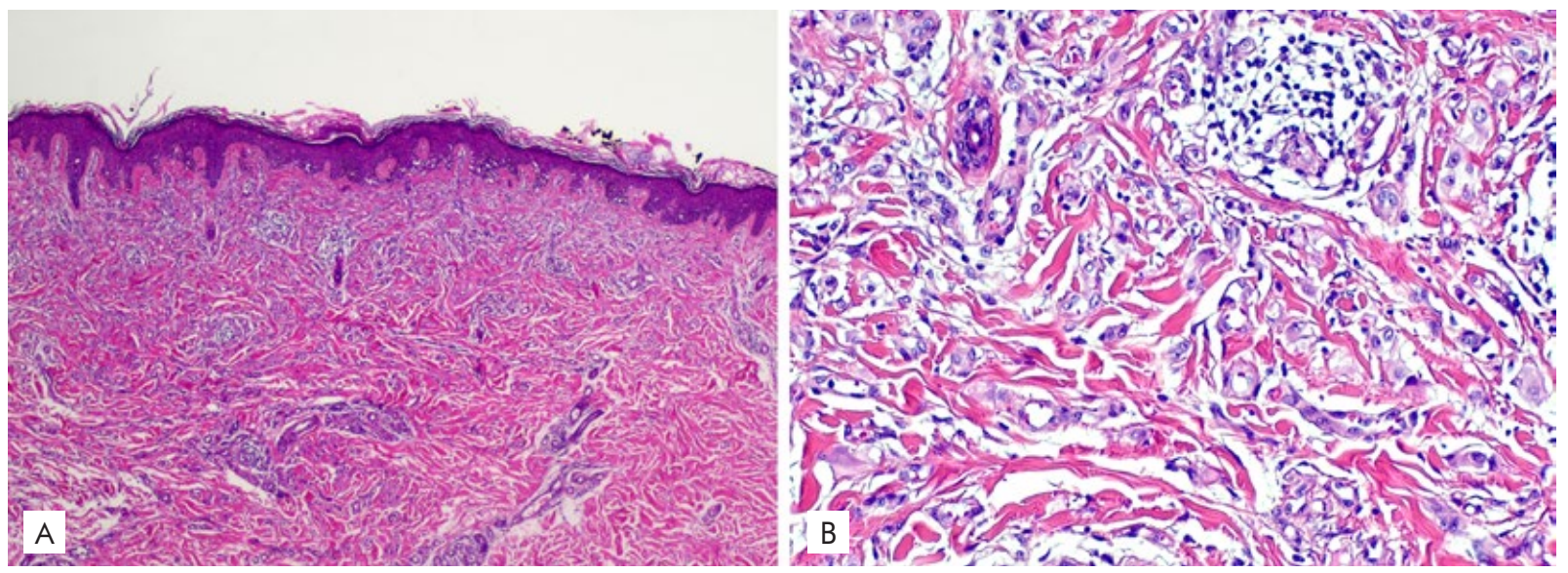

Figure 1 - Histology: The lesion is predominantly located in the dermis (A) and composed of spindled and epithelioid melanocytes with a prominent vascular and fibrogenic stromal response (B) [H\&E, original magnification 20x (A) and 100x (B)].

significant inflammatory infiltrate and melanin pigment. Immunostaining was positive within the melanocytes for both Melan-A (Fig. 2A) and S100 (Fig. 2B), and negative for podoplanin and HHV8. From these findings, the lesion was diagnosed as angiomatoid Spitz nevus (ASN).

\section{DISCUSSION}

ASN is a rare histological variant of desmoplastic Spitz nevus. First described in 2000 by Diaz-Cascajo, ${ }^{3}$ it is characterized by a proliferation of epithelioid and spindle-shaped melanocytes embedded in a prominent fibrous stroma with many densely arranged small blood vessels. Clinically, it presents as a popular dome-shaped lesion, usually solitary, often located on the extremities of young adults. Dermoscopic findings include an atypical pigmented network, wnite Iacunar zones, reaaısn nomogenous areas ana snort linear telangiectatic vessels. ${ }^{4}$ On histology, although some junctional or compound lesions have been described, the majority of tumors are purely dermal. Melanocytes, distributed mostly as solitary units, typically possess a plump nucleus with prominent nucleoli and abundant eosinophilic cytoplasm. Mitotic figures are rare and, when present, are confined to the upper dermis. Melanin pigment (present in $40 \%-83 \%$ of cases $^{3,5}$ ) is usually sparse and limited to the superficial component of the lesion. The fibrous stroma is composed of thick collagen bundles and a large number of small blood vessels. These are composed by plump endothelial cells without cellular atypia, lining a round or oval lumina. ${ }^{5}$ This vascular component consisting of a dermal proliferation vascular channels dissecting through collagen fibers may resemble a microvenular hemangioma. Vessel walls can be thick, thin, or mixed, potentially reflecting the tumor evolutionary stage. A mild to moderate perivascular inflammatory infiltrate consisting predominantly of lymphocytes is seen in most lesions. ${ }^{3}$

Differential diagnosis with malignant melanoma may be difficult, particularly with those with desmoplastic features or partial regression. ${ }^{6,7}$ However, melanocytes in
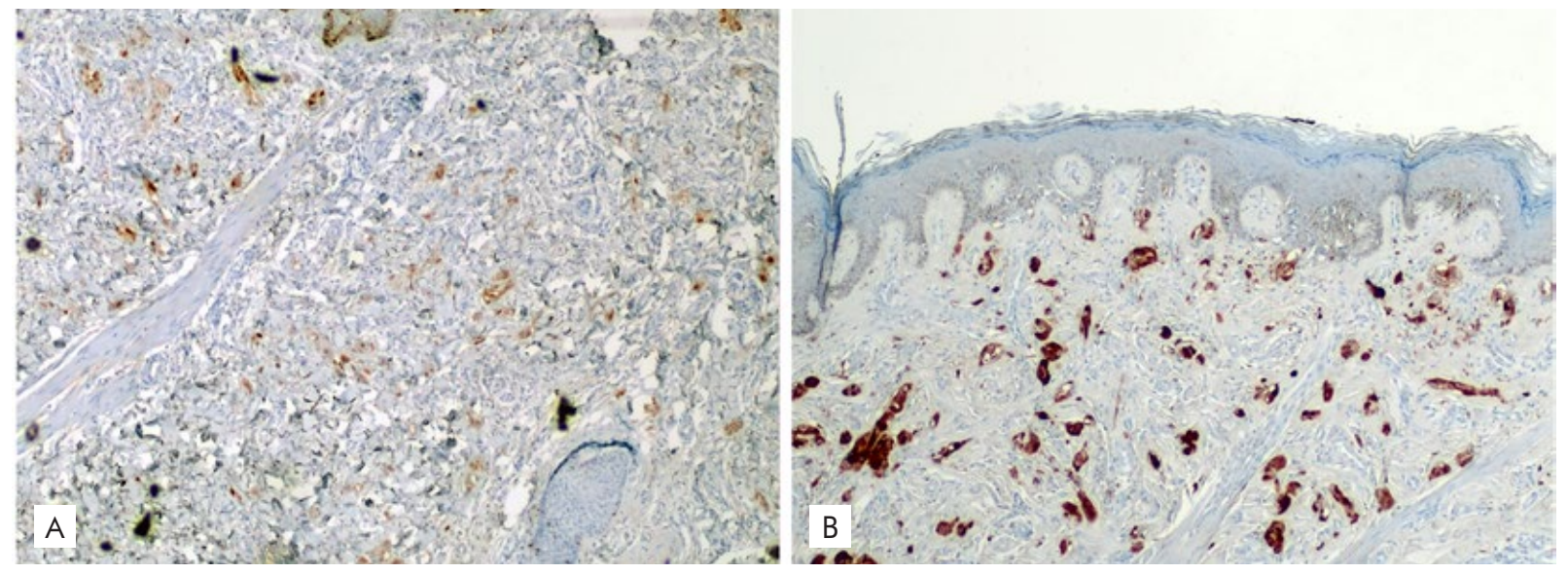

Figure 2 - Immunostaining: Positive within the melanocytes for both Melan-A (A) and S100 (B) (Original magnification, 40x). 


\section{Caso Clínico}

malignant melanoma often show more significant cytologic atypia and tendency to cluster, mitoses are more frequent and located in the deeper dermis, asymmetry is more pronounced and an epidermal component is often seen. Other differential diagnosis includes vascular tumors such as hemangiomas, sclerosing hemangioma type dermatofibroma and epithelioid cell histiocytoma ${ }^{3}$

Regarding the possible relation between the two proliferations (vascular and melanocytic), Helm and $\mathrm{Helm}^{8}$ challenge the idea of a simple coincidence. The authors point out that "the matching and intermingling silhouettes of the two proliferations provide compelling circumstantial evidence" that they may be related. Research on serpins shed a light on how melanocytes and blood vessels might interact and reveal a complex interaction between the tumor and surrounding stroma. ${ }^{9}$

The benign character of these lesions is supported by the absence of recurrences and metastases after complete excision during long-term follow-up. ${ }^{3,7}$

Conflitos de interesse: Os autores declaram a inexistência de conflitos de interesse na realização do presente trabalho.

Fontes de financiamento: Não existiram fontes externas de financiamento para a realização deste artigo.

Confidencialidade dos dados: Os autores declaram ter seguido os protocolos da sua instituição acerca da publicação dos dados de doentes.

Consentimento: Consentimento do doente para publicação obtido.

Proveniência e revisão por pares: Não comissionado; revisão externa por pares.

Conflicts of interest: The authors have no conflicts of interest to declare.

Financing support: This work has not received any contribution, grant or scholarship.

Confidentiality of data: The authors declare that they have followed the protocols of their work center on the publication of data from patients.

Patient Consent: Consent for publication was obtained.

Provenance and peer review: Not commissioned; externally peer reviewed

\section{ORCID}

J. Lopes

https://orcid.org/0000-0002-8874-8296

D. Afonso-João

https://orcid.org/0000-0003-3195-1207

D. Teixeira

https://orcid.org/0000-0002-5222-8192

\section{REFERENCES}

1. Menezes FD, Mooi WJ. Spitz tumors of the skin. Surg Pathol Clin. 2017; 10:281-98. doi: 10.1016/i. path.2017.01.004.

2. Ferrara G, Argenziano G, Soyer HP, et al. The spectrum of Spitz nevi: a clinicopathologic study of 83 cases. Arch Dermatol. 2005;141:1381-7. doi: 10.1001/archderm.141.11.1381.

3. Diaz-Cascajo C, Borghi S, Weyers W. Angiomatoid Spitz nevus: a distinct variant of desmoplastic Spitz nevus with prominent vasculature. Am J Dermatopathol. 2000; 22:135-9. doi: 10.1097/00000372-20000400000008.

4. Cabrera R, Daza F, Tom D, Castro A, Prieto VG. Dermatoscopy of an angiomatoid spitz nevus. Am J Dermatopathol. 2011; 33:628-30. doi: 10.1097/ DAD.0b013e318206c05f.

5. Tetzlaff MT, XU X, Elder DE, Elenitsas R. Angiomatoid Spitz nevus: a clinicopathological study of six cases and a review of the literature. J Cutan Pathol. 2009; 36:471-6. doi: 10.1111/i.1600-0560.2008.01060.x.

6. Fabrizi G, Massi G. Angiomatoid Spitz naevus: a close simulator of regressing malignant melanoma. Br J Dermatol. 2001 ; 145:845-6.

7. Rawson R, Robbins E, McCarthy SW, Scolyer RA. Angiomatoid Spitz naevus: novel observations and clues to diagnosis of a rare variant. Pathology. 2016; 48:73942. doi: 10.1016/i.pathol.2016.08.015.

8. Helm TN, Helm KF. Spitz nevus intermingling with hemangioma, angiomatoid Spitz nevus, angiotropism, and vascular co-option viewed with differing availability heuristics. Am J Dermatopathol. 2018; 40:465-7. doi: 10.1097/DAD.0000000000000870.

9. Valiente $M$, Obenauf $A C$, Jin $X$, Chen $Q$, Zhang $X H$, Lee DJ,et al. Serpins promote cancer cell survival and vascular co-option in brain metastasis. Cell. 2014; 156:1002-16. doi: 10.1016/i.cell.2014.01.040. 